\title{
Assessment of the Economic Pillar and Environmental Pillar of Sustainable Development in the European Union
}

\author{
Emília Huttmanová ${ }^{1}$ and Tomáš Valentiny ${ }^{1}$
}

\begin{abstract}
Sustainability is currently being implemented in a variety of activities. In practice, however, its achievement is complicated and difficult. In the process of achieving sustainability, it is essential to know the components of sustainable development and their current state. In general, sustainable development is perceived through four pillars - economic, social, environmental and institutional. In some cases, however, achieving a positive result in one of them could cause negative results in other(s). This inverse relationship can also be identified in the case of the economic and environmental pillar of sustainable development. The complexity of pillar's relations is one of the factors which causes considerable complicated achievement of sustainability. The difference of the individual pillars of sustainable development and difference in the individual European Union countries development (despite their relative homogeneity) is an object of our interest. The aim of the paper is to evaluate the current state and development of the economic and environmental pillar of sustainable development in EU countries, using selected indicators.
\end{abstract}

Keywords: sustainability, sustainable development, economic pillar, environmental pillar

\section{Introduction}

The issue of Sustainable Development (SD) has evolved and expanded throughout a long period till it created a holistic concept that currently includes a wide range of requirements. This situation also reflects the current expansion of goals that should lead to sustainability. The UN (2018) defined over the past year 17 sustainable development goals (SDGs) for both developed and developing economies. The modern approach to the SD leads through the co-operation of states, organizations and businesses, which is partly reflected in the current SDGs. However, the link between SD and business is still insufficient (Hall, Daneke and Lenox 2010) and one option is the concept of the cyclical economy (CE), which according to Geng and Doberstein (2008) provide a viable option for finding sustainable forms of development through (among others) the overall eco-efficiency of economic systems. The very concept of a cyclical economy has a longer history than sustainable development, which is based on the scarcity of resources and the effort of entities to minimize production costs (Gregson et al., 2015). Although, as Ghisellini, Cialani and Ulgiati (2016) claim, at present only a few countries have accepted, or is adopting initial actions to achieve the principles of cyclical economics (therefore stronger participation is needed), but both theoretically and 
practically the problem is primarily focused on the environmental economy and industrial ecology with a high emphasis on technological innovation in the form of cleaner technologies and improved recycling of materials. While for the EU, the goal is to reduce final waste production to the half its volume by 2050 compared to the end of last millennium, according to Fytili and Zabaniotas (2008) targeting priorities are as follows:

- waste prevention,

- minimizing the amount of waste generated,

- recovery of waste through re-use, recycling and energy savings,

- improved care conditions,

- transport regulation.

The search for a balance between sustainability and local (existing) implementation options has led to a further concept of so called eco-innovations, combining economic growth, employment and sustainable development, including the environmental pillar (European Commission, 2013). However, there is a need to develop national policies to support technological innovation and to encourage the development of supportive networks for economic competitiveness that will strengthen both industrial activities and sustainable growth associated with environmental protection (Frone and Constantinescu 2014). Thus, eco-innovation is the main engine of both sustainable development and cyclical economics. Based on the similarity between the two concepts and the factors influencing them, we will assume the relationship between cyclical economy indicators and SD indexes.

\section{Theoretical Background}

One of the earliest, most widely used and widely accepted SD definitions is the Brundtland definition (WCED 1987, p. 43), according to which "sustainable development is a development that meets the needs of the present without compromising the ability of future generations to meet their own needs". It contains within it two key concepts. The concept of 'needs', in particular the essential needs of the world's poor, to which overriding priority should be given and the idea of limitations imposed by the state of technology and social organization on the ability of the environment to meet current and future needs. A wide variety of definitions leads to the need for common feature specifications, as e.g. Demo et al. (2007) states, and these characteristics have been formulated as a targeted process of change in behaviour in the human society, understood as increasing the potential of meeting needs, ensuring intragenerational and intergenerational equality and living within the biosphere capacity. Mauerhofer (2008) in his work is also devoted to the three-dimensional approach to SD, which also links these aspects to concepts such as eco-effectiveness, eco-efficiency, socio-effectiveness, socio-efficiency, sufficiency or ecological equity. In addition to these pillars, some authors, e.g. Barkemeyer et al. (2014), Hahn et al. (2010), Adamišin (2008), Adamišin, Vavrek (2015) or Jackson (2009) are considering links and conflicts between sustainability, growth and prosperity. However, at present the concept as such is growing and considers an ever-wider spectrum of rules and relationships, which leads to the need 
for additional dimensions. According to Burford et al. (2013) all complementary pillars of sustainable development (cultural, institutional, and spiritual) are aimed at dealing with human values and how they affect personal and professional life.

The first option chosen to evaluate the achievement of SD objectives is the EPI index, which evaluates 180 countries using 24 performance indicators divided into 10 categories, providing the opportunity to evaluate countries within environmental policies and objectives while being able to provide information to countries aspiring to leadership in the achievement of sustainability (EPI 2018). In order to create an index, the data is transformed into a comparable form, and the "approach to goal" method is linked to the partial and total indexes. The objectives are the benchmark of the best results of international or national policy objectives, respectively scientifically validated (recognized) borders. Each indicator is weighted within its target, while the weighting for each new EPI index is set up by an expert panel. Two main objectives, i.e. environmental health and ecosystem vitality are weighted and combined to form a single value, the EPI index (Hsu et al., 2016). The list of all indicators used to compile the EPI index records figure 1 in the annexes.

Another option for SD quantification is the HDI index, which is regularly compiled by the UN. The HDI index was created to emphasize that people and their skills should be a crucial criterion in assessing the development of the country. The index is a summary of measured results achieved in the key dimensions of human development (dimensions indicators are given in brackets), which are a long and happy life (life expectancy at birth), whether educated (expected length of school attendance and average length of school attendance) the standard of living (Gross National Income per Capita), using a method of geometric mean and each of the dimensions is normalized by the so-called distance from the border (UN 2016). The index as such does not capture many aspects of the SD. One of these is the ethical paradox present in the SD issue, which is addressed by Grabara (2017). According to him, the concept of sustainable existence is based on the capacity of ecosystems on Earth, which lasted centuries without change. Therefore, we consider it necessary to extend the used HDI index. In addition, the HDI index is often criticized for a very strong link with aggregated landscape production. We consider the ESHDI index, which is an expanded form of the basic HDI index, as an appropriate option, taking into account the above-mentioned paradox and criticism. The fourth category entering it is an ecological footprint, but we do not consider it a simple environmental footprint per capita but as an ecological footprint of the country's total bio-capacities, standardized by the same method as the previous 3 categories (Ray 2012).

After defining sustainable development, respectively the two indexes selected, it is necessary to sufficiently break the issue of Circular Economy (CE). CE is an economic model where planning, resource finding, procurement, production and reprocessing are designed and managed both as a process and as an output to maximize the functioning of ecosystems and human well-being (Murray, Skene and Haynes 2017). Although the concepts of sustainability and cyclical economy are based on the same principles, there are some contradictions between them which summarize the group of authors around Geissdoerfer (2017). Authors include, among other things, the focus of objectives (broad-spectrum - S / closed cycle, ideal elimination of material inputs within the 
economy - CE), beneficiaries (environment, society and economy - S / Government and Enterprise - CE). The framework supporting CE implementation combines three main aspects, among which Lieder and Rashid (2016) advise waste and minimize environmental impacts, the scarcity of resources (motivating to the restoration of resource use), and the economic benefits to industrial enterprises under the conditions of sustainable and increasing profitability. Since CE is primarily business-oriented, Laubscher and Marinelli (2014) have identified key areas of CE integration into business models of business subjects. In addition, Mathewes and Tan (2011) Zhu, Geng and Lai (2010), Ying and Li-jun (2012); Bocken, de Pauw, Bakker and van der Grinten (2016); Sauve, Bernard and Sloan (2016) also deal with examples of cyclical economy.

\section{Methods and Variables}

Based on the factors described above, we have explored how the selected HDI, ESHDI and EPI indexes reflect developments in the cyclical economy, which has not only recently been one of the approaches to achieving sustainable development and is primarily linked to its economic and environmental aspects. This has resulted in the creation of functional relationships that look as follows:

$$
\begin{aligned}
& I=f(G D P p c, W G p c, M R) \\
& I=f(G D P p c, T R W, T I R W)
\end{aligned}
$$

where I represents indexes which are subject of impact assessment - HDI, ESHDI and EPI, GDPpc represents gross domestic product per capita, WGpc expresses waste production per capita, $M R$ describes the percentage of recycled waste from its total production, $T R W$ captures the total volume of recyclable waste (import - export), TIRW presents the recyclable waste import. The more specific description of the variables used provides the Table 1.

Table 1: List of variables

\begin{tabular}{|l|l|l|}
\hline Variable & Description & Source \\
\hline HDI & $\begin{array}{l}\text { Human Development Index. The variable represents the level } \\
\text { of the HDI index reached by a country in particular year on the } \\
\text { basis of the methodology established by the United Nations. } \\
\text { (dependent variable) }\end{array}$ & UN (2016) \\
\hline ESHDI & $\begin{array}{l}\text { The variable represents the level of the ESHDI index achieved } \\
\text { by the country determined in a given year on the basis of the } \\
\text { methodology established by the United Nations. (dependent } \\
\text { ariable) }\end{array}$ & UN (2016) a WWF (2016) \\
\hline EPI & $\begin{array}{l}\text { Environmental Performance Index. The variable records the } \\
\text { alue of a country-specific EPI at a given time based on the } \\
\text { methodology established at Yale University. (dependent } \\
\text { variable) }\end{array}$ & Hsu a kol. (2016) \\
\hline$G D P p c$ & $\begin{array}{l}\text { Gross domestic product per capita expressed in purchasing } \\
\text { power parity. The variable is a logarithmic value of aggregate } \\
\text { per capita production expressed by PPS. (independent variable) }\end{array}$ & Eurostat (2018) \\
\hline$W G p c$ & $\begin{array}{l}\text { Generation of waste per capita. The variable is determined by } \\
\text { the ratio of the total waste production (in tonnes) in given } \\
\text { country and the number of its population. (independent } \\
\text { variable) }\end{array}$ & Eurostat (2018) \\
\hline
\end{tabular}




\begin{tabular}{|l|l|l|}
\hline$M R$ & $\begin{array}{l}\text { Recycling of materials. The variable is characterized by the } \\
\text { proportion of materials that are recycled and the total waste } \\
\text { production. It therefore expresses the percentage of materials } \\
\text { revalued in the economy. (independent variable) }\end{array}$ & Eurostat (2018) \\
\hline TRW & $\begin{array}{l}\text { Trade in recyclable materials. The variable is defined as the } \\
\text { logarithm of the difference of import and export of recyclable } \\
\text { materials classified according to the JRC classification, divided } \\
\text { in the classes of plastics, paper and cardboard, iron and steel, } \\
\text { precious metals, copper, aluminum and nickel. (independent } \\
\text { variable) }\end{array}$ & Eurostat (2018) \\
\hline TIRW & $\begin{array}{l}\text { Import of recyclable materials. The variable is defined as the } \\
\text { logarithm of the import of recyclable materials classified } \\
\text { according to the JRC in the classes of plastics, paper and } \\
\text { cardboard, iron and steel, precious metals, copper, aluminum } \\
\text { and nickel. (independent variable) }\end{array}$ & Eurostat (2018) \\
\hline
\end{tabular}

\section{Data and Results}

The methods for quantification of relationships between HDI, ESHDI and EPI described above and a set of determinants representing the integration of the cyclical economy (to a certain extent) of a given regional entity were applied to a data sample representing 28 European countries capturing developments over a 10 -year period, namely the 2006-2016 period. Thus, the total size of the dataset for the HDI index, respectively for the ESHDI index was 280 observations, while for the EPI index it was 136 observations. This difference was due to the fact that the HDI and ESHDI indexes are compiled annually, while the EPI index is constructed every second year (and, in addition, all observed countries were not available in its first and second compilations). Based on these facts, we used panel regression, namely the Fixed Impact method. The decision to use this method was based on the Mean Significance Test, Breuch-Pagan Testing Statistics and Hausman Testing Statistics. But before that we determined whether the sample had a normal distribution.

The resulting coefficients of the selected regression analysis determinants for the entire observed sample are contained in Table 3.

Table 3: Regression models for total dataset

\begin{tabular}{|c|c|c|c|c|c|c|}
\hline & Model 1 & Model 2 & Model 3 & Model 4 & Model 5 & Model 6 \\
\hline Dependent variable: & HDI & ESHDI & EPI & HDI & ESHDI & EPI \\
\hline constant & 0,0220828 & 0,781237 & 39,7093 & $-0,171602$ & 0,817854 & $-1461,55$ \\
\hline & {$[0,0003]^{* * *}$} & {$[0,0012]^{* * *}$} & {$[0,0052]^{* * *}$} & {$[0,0087]^{* * *}$} & {$[0,0004]^{* * *}$} & {$[1,4 \mathrm{e}-06]^{* * *}$} \\
\hline$H D I_{t-1}$ & 0,969386 & & & 0,797613 & & \\
\hline & {$[7,6 \mathrm{e}-254]^{* * *}$} & & & {$[5,80 \mathrm{e}-93]^{* * *}$} & & \\
\hline$E S H D I_{t-1}$ & & 0,570911 & & & 0,567897 & \\
\hline & & {$[2,2 \mathrm{e}-27]^{* * *}$} & & & {$[2,04 \mathrm{e}-23]^{* * *}$} & \\
\hline$E P I_{t-2}$ & & & 0,252328 & & & 0,335273 \\
\hline & & & {$[0,0048]^{* * *}$} & & & {$[0,0013]^{* * *}$} \\
\hline $\ln (G D P p c)$ & 0,000214587 & $-0,0215857$ & 0,38457 & 0,0131022 & $-0,0193639$ & 63,1051 \\
\hline & {$[0,0881]^{*}$} & {$[0,0178]^{* *}$} & {$[0,4687]$} & {$[1,94 \mathrm{e}-05]^{* * *}$} & {$[0,0275]^{* *}$} & {$[3,41 \mathrm{e}-8]^{* * *}$} \\
\hline$W G p c$ & 0,00328119 & 0,0586947 & 2,68576 & & & \\
\hline & {$[0,0595]^{*}$} & {$[0,0003]^{* * *}$} & {$[0,6967]$} & & & \\
\hline$M R$ & $-0,000373945$ & $-0,0146208$ & 22,8644 & & & \\
\hline
\end{tabular}




\begin{tabular}{|c|c|c|c|c|c|c|}
\hline TRW & & & & $-0,0199065$ & 0,0242672 & 1881,34 \\
\hline & & & & {$[0,8746]$} & {$[0,9637]$} & {$[0,0038]^{* * *}$} \\
\hline$T I R W$ & & & & 0,000250408 & $-0,00345161$ & $-7,77409$ \\
\hline & & & & {$[0,5736]$} & {$[0,0565]^{*}$} & {$[0,0013]^{* * *}$} \\
\hline $\mathrm{R}^{2}$ & 0,99262 & 0,991694 & 0,239795 & 0,901121 & 0,991254 & 0,31372 \\
\hline
\end{tabular}

- - the constants for the individual cross-section units are located in the table 4

$*$, **, *** - represents statistical significance at the level $10 \%, 5 \%$, respectively $1 \%$

Source: own processing based on data from Eurostat 2018, WWF 2016, Hsu et al. 2016 and UN 2016

Table 4: Per unit constant for used fixed effect models

\begin{tabular}{|c|c|c|c|c|c|c|}
\hline & Model 1 & Model 2 & Model 3 & Model 4 & Model 5 & Model 6 \\
\hline Belgium & $-0,1933536$ & 0,863126 & 40,8487318 & $-0,1722373$ & 0,9036156 & $-1468,071$ \\
\hline Bulgaria & $-0,1952575$ & 0,7064972 & 38,61797652 & $-0,1741251$ & 0,7444497 & $-1393,561$ \\
\hline Czech Republic & $-0,1924254$ & 0,7867909 & 39,95498452 & $-0,1706079$ & 0,8141388 & $-1443,545$ \\
\hline Denmark & $-0,1750518$ & 0,7376055 & 39,78876175 & $-0,1575696$ & 0,7880714 & $-1436,436$ \\
\hline Germany & $-0,2160075$ & 0,8394539 & 44,03512520 & $-0,1927871$ & 0,8855170 & $-1575,427$ \\
\hline Estonia & $-0,1616631$ & 0,6705812 & 36,56304037 & $-0,1432885$ & 0,6954627 & $-1317,639$ \\
\hline Ireland & 337 & 0,738 & 39,71241923 & 6942 & & 150 \\
\hline Greece & $-0,1$ & 0,7 & 39,95 & 26995 & 235 & \\
\hline Spain & 976 & 308 & 6494 & 4041 & 3329 & 659 \\
\hline France & 264 & 648 & 332 & 2003 & 894 & 638 \\
\hline Croatia & 246 & 874 & 38,0 & 7190 & 739 & 228 \\
\hline Italy & 791 & 972 & 43,0 & 6043 & 2514 & 4,760 \\
\hline Cyprus & 2919 & 332 & 36,18 & 4803 & 2256 & 5,978 \\
\hline Latvia & $-0,1736721$ & 0,670 & 36,88351902 & 45789 & 0,7007283 & 4,202 \\
\hline Lithuan & 2089 & 0,7044731 & 37,8 & 67084 & 3674 & 161 \\
\hline Luxembou & 867 & & 37,2 & 2789 & 3180 & 506 \\
\hline Hungary & & & 39,5 & 366 & 063 & 246 \\
\hline Malta & & & 35,1 & 225 & 164 & 942 \\
\hline Netherlan & 911 & 61 & 41,5 & 1939 & 0,9120958 & 244 \\
\hline Austria & 392 & 0,77 & 40,3 & 7161 & 0,8160905 & $-1452,637$ \\
\hline Poland & 253 & 381 & 7919 & 83086 & 0,8277915 & $-1511,376$ \\
\hline Portugal & $-0,1981561$ & 0,7818778 & 39,81343812 & $-0,1763229$ & 0,8174799 & $-1444,090$ \\
\hline Romania & $-0,2102289$ & 0,7411093 & 40,29736915 & $-0,1860965$ & 0,7628609 & $-1473,800$ \\
\hline Slovenia & 2217 & 0,7428488 & 37,50217047 & $-0,1464416$ & 0,7812035 & $-1350,270$ \\
\hline Slovakia & & & 38,58 & 5984 & &, 490 \\
\hline Finland & & & & 226 & 0,7 &, 128 \\
\hline Sweden & & 226 & 40,4 & 7940 & 0,7 & $-1456,496$ \\
\hline United Kingdo & $-0,2146689$ & 0,8654555 & 43,23037280 & $-0,1913818$ & 0,9050621 & $-1559,119$ \\
\hline
\end{tabular}

Source: own processing based on data from Eurostat 2018, WWF 2016, Hsu et al. 2016 and UN 2016

In the case of the HDI index and the cyclical economy in the field of the production and consumption (model 1), there is a clear link with the growth of the natural GDP logarithm to the HDI index growth, this factor as a variable enters the calculations of this index. However, it is statistically significant only at the level of significance $a=0.10$ and this state is caused by the form itself, which brings the level of aggregated landscape production into the calculation. Since it is constructed as a distance from the border, it also has a significant impact on GDP per capita of economically the most developed and economically least-developed country, which then hopes for a slight decrease in the significance of the factor. Also, the increase in per capita waste 
production contributes to raising the score obtained in the HDI index. But just like GDP is significant only on $10 \%$ level of statistical significance, the same is true for the waste generation factor. This is mainly due to the fact that the index as such does not take into account the impact of the accumulation of waste on the capacity of the environment and its effects are largely long-term. Also in particular, the effects of aggregated production and waste generation are manifested. Material recycling is an indifferent determinant of changes in the HDI index, as businesses can save on the cost of materials while recycling, but mining and processing companies have a lower demand for their production. This, as well as the absence of the direct influence of the material extraction in the country on the HDI variable system, led to this state. If we considered the dependent variable as an ESHDI index (model 2), the situation was more pronounced in the case of the indicator of the logarithm of aggregated production, which had exactly the opposite effect as in model 1. This condition is related to the fact that another factor enters index; namely ecological footprint reflecting the country's bio-capacity. In increasing production, the economic and social components of the index are growing, but the negative impact of the population on the environment (the environmental component of the index) is growing significantly. In addition, the factor of waste production was slightly more significant and, above all, more intense. Higher levels of waste generation lead to ever greater pressure on the environment and the greater damage caused by the local population. The impact of the same mix of determinants on country level reached in the EPI index (model 3) recorded the exact opposite of the previous examples. The insignificant factors of the economic aspect of the cyclical economy (GDP per capita and per capita waste generation) show that the absence of the EPI index more closely evaluates the interconnection of environmental impacts with a certain level of output (even economic output). However, the material recycling factor is statistically significant and represents a significant impact from which we can assume that a one-percent increase in recycling of materials should increase the EPI index by 0.23 points. However, in the longer term, the impact of this factor should increase, as the accumulation of companies able to retrieve waste from the manufacturing process, in view of the synergistic effect, should put additional pressure on further reductions in the prices of the recycled materials, further encouraging the organization to participate on the functioning of the cyclical economy. However, it should be added that the first two models (4 times) more precisely explain the behaviour of the dependent variable (index) than in the case of the third model. Thus, the HDI and ESHDI indexes more closely expresses the aspect of production and consumption within the cyclical economy than for the EPI index.

Subsequently, the waste management component was evaluated in the cyclical economy. This component represents the total recyclable waste variable that is calculated as the difference between import and export of this commodity and the total amount of import of recyclable waste. While the first factor tells us the current status and structure of the use of specific types of materials (able to be recycled) in the country, which is the potential of the country for further additional recycling. The second factor focuses exclusively on the import of these materials, thus structuring the first variable. In addition, we included the natural GDP per capita logarithm and the result factor of previous index. Thus, model 4, which deals with HDI index and waste management, 
shows that both factors are indifferent to it. Basically, it's the same principle as recycling materials. This time, however, it is not the actual recycling itself, but the recycling potential through the structure of the materials used. Therefore, again, we assume (on the basis of similar principles as in the case of recycling materials) that the impact of this factor will be more of a longer-term nature. When assessing an independent variable defined as ESHDI with regard to the mix of waste management indicators (Model 5), the situation changed slightly from the previous model. The change in case of the GDPpc variable reflects the situation described above, which also reflects the damage caused by the population (ecological footprint). However, this time an overall import of recyclable waste is also a significant factor. If the economy imports recyclable waste, it is looking for a new and cheaper way of getting inputs or replacing them, which may leads to increased production (but also to resistant, non-recyclable waste). Therefore, this factor has been indirectly related to the value of the ESHDI index. Another important factor is that this model, by about $9 \%$, better reflects the volatility of the independent variable. Model 6 representing the dependence of EPI index development on waste management assumes statistical significance for all variables used, but explains the development of the dependent variable only to about one-third. This condition is related to the fact that the factors (apart from the immediately preceding value of the EPI index) are influenced by two opposing tendencies. The GDP per capita figure was directly proportional to the EPI index. The increase in production itself mainly leads to an increase in environmental pressure and intensification of its use; for developed countries in the EU, this GDP growth is partly linked to an increase in services that have a significantly lower impact on the environment and hence on the EPI index. In addition, wealthy states are more concerned about saving the environment they live in. The growth factor of the total amount of recyclable waste positively affects the EPI index. The change in the structure of waste is related to the fact that, in the context of innovation and investment, the enterprises that use "waste" from the production of other business entities, respectively international trade is used to sell and purchase these materials, which can be recycled elsewhere. In the case of comparison of models 4, 5 and 6, there is a similar situation as in the case of the first three, actually that model 4 and model 5 strongly predicts the development of HDI, respectively ESHDI than index 6 - EPI. However, HDI does not contain the impact of the waste management (in the case of ESHDI, only imports are affected), while it is so in the case of EPI. Thus, the EPI shows more clearly the essence of the waste management aspect within the cyclical economy and the precision of the first two models is primarily based on the interdependence of the HDI index, or ESHDI variations with the size of the country's aggregate production.

\section{Discussion and Conclusion}

Eco-efficiency in input processing within the production process and the production of products from which the largest possible amount of material can be recycled is one of the possibilities of linking the SD and CE concepts. Therefore, we have decided to subject some of its factors to an analysis that determines the relationship with selected SD indicators. Not only recently, some authors (Welford 2013, Barkemeyer, Holt, Preuss, and Tsang 2014) often criticize excessive interest in the 
economic component of SD, which, in their view, leads too much to economic development rather than sustainable development. CE is not fully able to substitute for $\mathrm{SD}$, but we can see this as the initial step of government and businesses that will lead to sustainability. On the basis of the analysis results, we have confirmed the frequent criticism of the HDI index and its links with aggregate production. However, the modified ESHDI index represents a much better option of assessing sustainability, even in the case of the CE concept, which also counts with GDP, but the pressure of high production on the environment is reflected in a negative relationship.

This index is therefore able to evaluate changes in production processes that have not yet reached the required level. Generating waste just underlines the problem of high production and high consumption of goods and services. The EPI index within this area can reflect on the proportion of materials recycled in the economy. In the area of waste management, this index also reached a certain degree of interconnectivity, reflecting the dependence both on the total amount of waste generated and on its import, with this factor being also related to the ESHDI indicator. Consequently, the ESHDI and EPI indicators are a relatively good measure of progress in the CE area, provided that these indices join together. Such an indicator could then be a good opportunity to determine the current state of application of the CE principles but would still be a reliable form in the SD concept.

\section{Acknowledgements}

This article is supported by Project KEGA 038PU-4/2018 "Rozvoj študijného programu Environmentálny manažment v II. stupni štúdia” and Project VEGA 1/0578/18 "Modifikácia metodík pre hodnotenie a manažment udržatel'ného rozvoja"

\section{References}

Adamišin, Peter. Macroeconomic coherences of regional development in the Slovak republic. In: Hradecké ekonomické dny 2008: aktualni problemy rozvoje regionu. 7-11, ISBN 978-80-7041-190-2.

Adamišin, Peter and Roman Vavrek. Analysis of the links between selected socio-economic indicators and waste management at the regional level in the Slovak republic. In: 5 th Central European conference in regional science : conference proceedings. Košice : Technical university of Košice, 2015. 1-9. ISBN 978-80-553-2015-1.

Barkemeyer, Ralf, Holt, Diane, Preuss, Lutz and Stephen Tsang, 2014. What happened to the development in 'sustainable development'? Sustainable Development, 22.1: 15-32, ISSN 1099-1719.

Bocken, Nancy, De Pauw, Ingrid, Bakker, Conny and Bran Van Der Grinten, 2016. Product design and business model strategies for a circular economy. Journal of Industrial and Production Engineering, 33.5: 308-320, ISSN 2168-1023.

Burford, Gemma, Hoover, Elona, Velasco, Ismael, Janoušková, Svatava, Jimenez, Alicia, Piggot, Georgia. Podger, Dimity and Marie K. Harder, 2013. "Bringing the 'Missing Pillar' into sustainable development goals: towards intersubjective values-based indicators", Sustainability, 5.7: 3035-3059, ISSN 2071-1050.

Demo, Milan et al., 2007. Udržatelný rožoj: život v medziach únosnej kapacity biosféry. Nitra: SPU, 440 s., ISBN 97880-8069-826-3.

Európska Komisia, 2013. Technology and Innovation in energy field, $\operatorname{COM}(2013) 253$ final.

EPI 2018. EPI Policymakers' Summary. Citované [20.02.2018], Dostupné na internete: $<$ https://epi.envirocenter.yale.edu/downloads/epi2018policymakerssummaryv01.pdf>.

Frone, Simona and Andreea Constantinescu, 2014. Impact of Technological Innovation on the Pillars of Sustainable Development. Calitatea, 15.S1: 69, ISSN 1582-2559. 
Fytili, Despoina and Anastasia Zabaniotou, 2008. Utilization of sewage sludge in EU application of old and new methods - a review. Renewable \& Sustainable Energy Reviews, 12.1: 116-140, ISSN 1364-0321.

Geissdoerfer, Martin, Savaget, Paulo, Bocken, Nancy and Erik Hultink, 2017. The Circular Economy - a new sustainability paradigm? Journal of Cleaner Production, 143.2017: 757-768, ISSN 0959-6526.

Geng Yong and Brent Doberstein, 2008. Developing the circular economy in China: Challenges and opportunities for achieving 'leapfrog development'. International Journal of Sustainable Development \& World Ecology, 15.2008: 231-239, ISSN 1350-4509.

Ghisellini, Patrizia, Cialani, Catia and Sergio Ulgiati, 2016. A review on circular economy: the expected transition to a balanced interplay of environmental and economic systems. Journal of Cleaner Production, 114. 2016: 11-32, ISSN 0959-6526.

Grabara, Janusz, 2017. The another point of view on sustainable management. Calitatea, 18.S1: 344-349, ISSN 1582-2559.

Gregson, Nicky, Crang, Mike, Fuller, Sara and Helen Holmes, 2015. Interrogating the circular economy: the moral economy of resource recovery in the EU. Economy and Society, 44.2: 218-243, ISSN 1469-5766.

Hahn, Tobiass, Figge, Frank., Pinkse Jonatan and Lutz Preuss, 2010. Trade-offs in corporate sustainability: You can't have your cake and eat it. Business Strategy and the Environment, 19.4: 217-229, ISSN 1099-0836.

Hall, Jeremy, Daneke, Gregory and Michael Lenox, 2010. Sustainable development and entrepreneurship: Past contributions and future directions. Journal of Business Venturing, 25.2010: 439-448, ISSN 0883-9026.

Hsu, Angel et al., 2016. 2016 Environmental Performance Index. New Haven, CT: Yale University. Citované [22.02.2018], Dostupné na internete: <www.epi.yale.edu>.

Jackson, Tim, 2009. Prosperity Without Growth? The Transition to a Sustainable Economy. UK Sustainable Development Commission, London: Výskumná správa.

Laubscher, Markus and Thomas Marinelli, 2014. Integration of Circular Economy in Business. In Proceedings of the Conference: Going Green—Care Innovation 2014, Vienna, Austria, 17-20 November 2014.

Lieder, Michael and Amir Rashid, 2016. Towards circular economy implementation: a comprehensive review in context of manufacturing industry. Journal of Cleaner Production, 115.2016: 36-51, ISSN 0959-6526.

Majerník, Milan, Chovancová, Jana, Daneshjo, Naqib and Enayat Daneshjo, 2015. Environmental and health impact assessment of development strategies . 1. eds. Düsseldorf : Albersdruck GmbH \& Co. KG, 2015. 148 pp. ISBN 978-3-00-050052-7.

Mathews, John and Hao Tan, 2011. Progess Toward a Circular Economy in China. Journal of Industrial Ecology, 15.3: 435-457, ISSN .1530-9290.

Mauerhofer, Volker, 2008. 3-D Sustainability: An approach for priority setting in situation of conflicting interests towards a Sustainable Development. Ecological Economics, 64.2008: 496-506, ISSN 0921-8009.

Murray, Alan, Skene, Keith and Kathryn Haynes, 2017. The Circular Economy: An Interdisciplinary Exploration of the Concept and Application in a Global Context. Journal of Business Ethics, 140.3: 369380, ISSN 1573-0697.

Ray, Mona, 2012. Accounting for Sustainability-Greening the Human Development Index. In: International Conference on Micro and Macro Economics Research (MME). Proceedings. Global Science and Technology Forum, 2012. p. 71.

Sauvé, Sébastien, Bernard, Sophie and Pamela Sloan, 2016. Environmental sciences, sustainable development and circular economy: Alternative concepts for trans-disciplinary research. Environmental Development, 17.2016: 48-56, ISSN 211-4645.

UN 2016. Human Development Report. United Nations Development Programme: New York, 286 s., ISBN 978 92-1-126413-5.

UN 2018. Sustainable Development Goals: 17 Goals to Transform Our World. Citované [25.2.2018], dostupné na: $<$ http://www.un.org/sustainabledevelopment/sustainable-development-goals/>

WCED, 1987. Our Common Future. World Commission on Environment and Development: Výskumná správa, s. 43.

Welford, Richard, 2013. Hijacking environmentalism: Corporate responses to sustainable development. New York: Routledge, 250 s., ISSN 978-1-85383-398-4.

Ying, Jiang a Zhou LI-JUN, 2012. Study on green supply chain management based on circular economy. Physics Procedia, 25.2012: 1682-1688, ISSN 1875-3892.

Zhu, Qinghua, Geng, Yong a Kee-Hung LAI, 2010. Circular economy practices among Chinese manufacturers varying in environmental-oriented supply chain cooperation and the performance implications. Journal of Environmental Management, 91.6: 1324-1331, ISSN 0301-4797. 